\title{
Noise Induced Hearing Loss in Ground Handling Workers at Juanda Airport Surabaya
}

\author{
Citra Dwi Novastuti, Nyilo Purnami (D), and Nugraenny Affianti \\ Department of Otorhinolaryngology-Head and Neck Surgery, Faculty of Medicine, Universitas Airlangga, Dr. Soetomo General Hospital, \\ Surabaya, Indonesia
}

Received May 9, 2019

Revised August 16, 2019

Accepted August 23, 2019

Address for correspondence

Nyilo Purnami, PhD

Department of Otorhinolaryngology-

Head and Neck Surgery,

Faculty of Medicine,

Universitas Airlangga,

Dr. Soetomo General Hospital,

Prof. Dr. Moestopo 6-8,

Surabaya 60286, Indonesia

Tel +62-815-5100-081

Fax $+62-31-5010887$

E-mail nyilo@fk.unair.ac.id
Background and Objectives The airport ground handling workers are most vulnerable to noise exposure from the sound of aircraft engines that are quite loud and, if exposed continuously, they may experience hearing loss. This study describes the profile of noise induced hearing loss in ground handling workers at Juanda Airport Surabaya.

Subjects and Method The descriptive cross sectional approach is employed, and the noise level in the work environment is measured by airport apron, physical ear examination, distortion product otoacoustic emission (DPOAE) and pure tone audiometry, which were conducted for 89 ground handling workers at the airport.

Results The age range that experienced hearing loss the most is $50-59$ years $(19.10 \%)$. The male: female ratio of subjects who experienced hearing loss was 50\%:53.24\%. The highest percentage of subjects with hearing loss was found in the Area II (export-import cargo) with $68 \%$. Workers who experience hearing loss the most have been working for $17-21$ years $(76 \%)$. The ratio of hearing loss between continuous users of ear protectors and occasional or non-users of protectors was $22.47 \%: 30.34 \%$. Of the 89 total research subjects, 47 were found with hearing based on the DPOAE refer results; of these subjects, $30(33.7 \%)$ experienced hearing loss due to noise (NIHL), 9 suffered in the right ear (10.11\%), 9 in the left ear (10.11\%) and 12 in both ears (13.48\%).

Conclusion Based on the DPOAE results, $52.81 \%$ of the ground handling workers at Juanda airport Surabaya were found with hearing loss; of these workers, $33.7 \%$ workers experienced NIHL with $10.11 \%$ observed in each ear and $13.48 \%$ in both ears.

Korean J Otorhinolaryngol-Head Neck Surg 2020;63(2):59-63

Key Words Hearing loss $\cdot$ Noise-induced · Occupational.

\section{Introduction}

Hearing loss is currently still a world health problem. The World Health Organization (WHO) reports that 466 million people in the world currently suffer from hearing loss. WHO also warned 1 in 10 people at the global level, or more than 900 million people would be at risk of losing their hearing senses by the year $2050 .{ }^{1)}$ WHO data reports that $16 \%$ of hearing loss in adults is due to occupational noise exposure. The incidence rate will continue to increase, especially on

This is an Open Access article distributed under the terms of the Creative Commons Attribution Non-Commercial License (https://creativecommons.org/licenses/by-nc/4.0) which permits unrestricted non-commercial use, distribution, and reproduction in any medium, provided the original work is properly cited. developing countries. ${ }^{2)}$

Noisy is an unwanted sound with various negative effects. Noise can cause health problems in the form of noise induced hearing loss (NIHL). The NIHL description of the audio inspection in the form of a notch at a frequency of $4000 \mathrm{~Hz}$ and $6000 \mathrm{~Hz}$ was first discovered by Fowler in 1939.") One work environment that can cause noise is at the airport. At the airport we can find noise that is quite loud especially in the ground handling section. This noise comes from the sound of the aircraft engine.

The Indonesian Government through the Ministry of Labor and Transmigration has set a maximum threshold value of $85 \mathrm{~dB}$ (A) for the exposure time of 8 hours a day and 40 
hours a week. This is in accordance with the Ministry of Labor and Transmigration of the Republic of Indonesia Regulations number 13/MEN/X/2011 concerning the threshold value of physical factors and chemical factors in the workplace. If workers in the ground handling section are exposed to noise continuously, then it is possible that the worker will experience hearing loss. ${ }^{4}$

This study aims to provide an overview of the profile of hearing loss in ground handling workers at Juanda Airport Surabaya.

\section{Subjects and Method}

Type of research is a descriptive study with a cross sectional approach, datas were collected at 89 ground handling workers at Juanda Airport in Surabaya. The inclusion criteria include subject agreed to be research sample by filling out informed consent, aged between 20-60 years, working period of more than 2 years, good health condition and not in a state of illness. Exclusion criteria include subject had a middle ear infection or other ear disease that causes hearing loss, anatomical abnormalities or tumors in the ear, nose and throat area. Subjects were selected by random sampling technique among 215 ground handling workers at Juanda airport. Independent variable in this study is noise level at the working areas Juanda airport, while dependent variable is the hearing threshold of ground handling workers at Juanda airport Surabaya. This study has been validated for ethical clearance at Faculty of Medicine Universitas Airlangga with Institutional Review Board No. 245/EC/KEPK/FKUA/2018.

The research instrument used was Benetech GM 1356 sound level meter (Shenzhen Jumaoyuan Science and Technology Co., Ltd, shenzhen, China), GSI Arrow Audiometer (Grason Stadler, Eden Prairie, MN, USA), Biologic AudX Pro II-e3 DPOAE (Natus Medical Incorporated, Mundelein, IL, USA), and questionnaires. This research was conducted on October 2018 at the Juanda airport apron in Surabaya, inside 2 nd floor building with noise level measurement results below $40 \mathrm{~dB}$. Research procedures included the selection of research subjects according to inclusion and exclusion criteria then the samples were managed based on complete history, ENT clinical examination, pure tone audiometry and distortion product otoacoustic emission (DPOAE) examination. Noise level measurement was carried out at several points of the working areas at airport apron. The datas collected were grouped and presented in tables. The results were analyzed by IBM Corp., version 23 for Windows (Armonk, NY, USA). Chi-square test were used for the assessment of level of significance.

\section{Results}

Data on research subjects were divided based on a certain range. From the data, the majority of the research subjects were between 40-49 years old, there were 31 subjects (34.83\%). From these data, the mean value is 41.01 (Standard deviation \pm 10.39 ). Based on Table 1, it can be seen that in the age range of 20-29 years, the age range of 30-39 years, and the age range of 40-49 years, the most are workers with normal hearing, whereas in the age range of 50-59 years more hearing loss occurs bilateral type (13.48\%). Unilateral and bilateral hearing loss most occur at the age of 50-59 years $(19.10 \%)$, followed by age $40-49$ years $(17.98 \%)$. There are differences in the distribution of hearing loss based on age with level of significance ( $p=0.02$ ).

Based on the data of the subjects in this study, the gender of the research subjects was mostly dominated by men, namely as many as 77 subjects $(86.52 \%)$, while the female subjects in this study were 12 people $(13.48 \%)$. The gender ratio of male and female subjects in this study was 6.4:1. The percentage of subjects who experienced hearing loss based on male compared to women was $50 \%: 53.24 \%$. There is no difference in the distribution of hearing loss based on gender with level of significance $(p=0.83)$ (Table 2$)$.

The data shows that the subjects in this study had a majori-

Table 1. Distribution of hearing loss based on age according to the ear affected

\begin{tabular}{lcccc}
\hline $\begin{array}{c}\text { Age range } \\
\text { (years) }\end{array}$ & Both normal & Unilateral & Bilateral & Total \\
\hline $20-29$ & $11(12.36)$ & $3(3.37)$ & $3(3.37)$ & $17(19.10)$ \\
$30-39$ & $11(12.36)$ & $5(5.62)$ & $3(3.37)$ & $19(21.35)$ \\
$40-49$ & $15(16.85)$ & $5(5.62)$ & $11(12.36)$ & $31(34.83)$ \\
$50-59$ & $5(5.62)$ & $5(5.62)$ & $12(13.48)$ & $22(24.72)$ \\
\hline Total & $42(4719)$ & $18(20.23)$ & $29(32.58)$ & $89(100)$ \\
\hline
\end{tabular}

Variables are presented as number (percentage). $p=0.02$

Table 2. Distribution of hearing loss based on gender according to the ear affected

\begin{tabular}{lcccc}
\hline Gender & $\begin{array}{c}\text { Both ears } \\
\text { normal }\end{array}$ & Unilateral & Bilateral & Total \\
\hline Male & $36(40.45)$ & $15(16.86)$ & $26(29.21)$ & $77(86.52)$ \\
Female & $6(6.74)$ & $3(3.37)$ & $3(3.37)$ & $12(13.48)$ \\
\hline Total & $42(47.19)$ & $18(20.23)$ & $29(32.58)$ & $89(100)$ \\
\hline
\end{tabular}

Variables are presented as number (percentage). $p=0.83$ 
ty of their working period between 7-11 years, namely as many as 25 people (28.09\%). Subjects whose working period is between 2-6 years are 24 people (26.96\%). Subjects whose working period was $17-21$ were 17 people (19.10\%). Subjects whose work period was $\geq 22$ years were also 17 people $(19.10 \%)$. And as many as 6 people $(6.75 \%)$ have worked for 12-16 years. Unilateral and bilateral hearing loss most occur in workers with a work period of 17-21 years (76\%). There are differences in the distribution of hearing loss based on

Table 3. Distribution of hearing loss based on working periode to the ear affected

\begin{tabular}{lcccc}
\hline $\begin{array}{c}\text { Working } \\
\text { Periode (years) }\end{array}$ & $\begin{array}{c}\text { Both ears } \\
\text { normal }\end{array}$ & Unilateral & Bilateral & Total \\
\hline $2-6$ & $15(16.86)$ & $4(4.49)$ & $5(5.62)$ & $24(26.96)$ \\
$7-11$ & $14(15.73)$ & $5(5.62)$ & $6(6.74)$ & $25(28.09)$ \\
$12-16$ & $3(3.37)$ & $2(2.25)$ & $1(1.12)$ & $6(6.75)$ \\
$17-21$ & $4(4.49)$ & $3(3.37)$ & $10(11.24)$ & $17(19.10)$ \\
$\geq 22$ & $6(6.74)$ & $4(4.49)$ & $7(7.87)$ & $17(19.10)$ \\
\hline Total & $42(47.19)$ & $18(20.22)$ & $29(32.59)$ & $89(100)$ \\
\hline
\end{tabular}

Variables are presented as number (percentage). $p=0.01$

Table 4. Distribution of hearing loss based on the use of ear protectors to the ear affected

\begin{tabular}{lcccc}
\hline $\begin{array}{l}\text { Ear protectors } \\
\text { usage }\end{array}$ & $\begin{array}{c}\text { Both ears } \\
\text { normal }\end{array}$ & Unilateral & Bilateral & Total \\
\hline Yes & $23(25.84)$ & $5(5.62)$ & $15(16.85)$ & $43(48.31)$ \\
No & $19(21.35)$ & $13(14.61)$ & $14(15.73)$ & $46(51.69)$ \\
\hline Total & $42(47.19)$ & $18(20.23)$ & $29(32.58)$ & $89(100)$ \\
\hline
\end{tabular}

Variables are presented as number (percentage). $p=0.15$ working periode with level of significance $(p=0.01)$ (Table 3).

From the data, it was found that from 89 subjects in this study, 46 people $(51.69 \%)$ did not use ear protectors (EP) in the form of ear plug/ear muff, and 43 (48.31\%) used ear protection devices in the form of ear plug/ear muff. The percentage of workers who experience hearing loss between those using EP compared with those who do not or rarely use EP is $22.47 \%: 30.34 \%$. There is no difference in the distribution of hearing loss based on the use of ear protectors with level of significance $(p=0.15)$ (Table 4$)$.

The working area is divided into 5 areas with the results of measurement with sound level meters. The results are mean or average noise in each area as shown in Table 5. Each of working area is further divided into several sections of work. The data shows that the subjects in this study mostly worked on the silver ramp section as many as 18 people (20.23\%) and also on the apron services section with a total of 18 research subjects $(20.23 \%)$. The percentage of workers who experience the most unilateral and bilateral hearing loss is in area II (export-import) which is $68 \%$. While the percentage of workers who experienced the least impaired hearing was in area I (Administration), which was $44 \%$. There are no differences in the distribution of hearing loss based on working area in the airport apron with significance level ( $p=0.74$ ).

The data in Table 6 shows 47 workers (52.81\%) with DPOAE refer results. The data in Table 7 shows that workers with DPOAE refer got 17 workers (19.11\%) experiencing

Table 5. Distribution of hearing loss based on working area, working section to the ear affected

\begin{tabular}{|c|c|c|c|c|c|}
\hline Working area & Working section & Both ears normal & Unilateral & Bilateral & Total \\
\hline Area I & Human capital & $2(2.25)$ & $0(0)$ & $0(0)$ & $2(2.25)$ \\
\hline \multirow[t]{3}{*}{ administration $( \pm 57.8 \mathrm{~dB})$} & Finance \& accounting & $0(0)$ & $1(1.12)$ & $0(0)$ & $1(1.12)$ \\
\hline & Ground station & $0(0)$ & $1(1.12)$ & $0(0)$ & $1(1.12)$ \\
\hline & General Affair services \& procurement & $3(2.25)$ & $0(0)$ & $2(3.37)$ & $5(5.62)$ \\
\hline Area $\|$ & Control cargo & $0(0)$ & $2(2.25)$ & $0(0)$ & $2(2.25)$ \\
\hline \multirow[t]{3}{*}{ export-import $( \pm 66.2 \mathrm{~dB})$} & Import cargo & $1(1.12)$ & $1(1.12)$ & $2(2.25)$ & $4(4.49)$ \\
\hline & Porter & $1(1.12)$ & $2(3.37)$ & $2(2.25)$ & $5(5.62)$ \\
\hline & Export cargo & $4(4.49)$ & $1(1.12)$ & $3(3.37)$ & $8(8.99)$ \\
\hline Area III & Check in \& gate silver & $0(0)$ & $1(1.12)$ & $0(0)$ & $1(1.12)$ \\
\hline passengers coordinator & Passenger services & $2(2.25)$ & $2(2.25)$ & $0(0)$ & $4(4.49)$ \\
\hline$( \pm 70.5 \mathrm{~dB})$ & Avsec & $7(7.87)$ & $0(0)$ & $5(5.62)$ & $12(13.48)$ \\
\hline Area IV & Load master & $1(1.12)$ & $0(0)$ & $0(0)$ & $1(1.12)$ \\
\hline luggage supervisor $( \pm 73.1$ dB) & $\begin{array}{l}\text { Ground support equipment \& } \\
\text { maintenance services }\end{array}$ & $2(4.49)$ & $2(0)$ & $3(3.37)$ & $7(7.87)$ \\
\hline Area $\vee$ & Apron services & $10(11.24)$ & $3(3.37)$ & $5(5.62)$ & $18(20.23)$ \\
\hline aircraft coordinator $( \pm 83.7 \mathrm{~dB})$ & Ramp silver & $8(8.99)$ & $4(4.49)$ & $6(6.74)$ & $18(20.23)$ \\
\hline Total & & $42(47.19)$ & $18(20.23)$ & $29(32.58)$ & $89(100)$ \\
\hline
\end{tabular}

Variables are presented as number (percentage). $p=0.74$ 
SNHL and 30 workers (33.7\%) experiencing noise induced hearing loss (NIHL). Workers who experienced NIHL as many as 9 workers in the right ear (10.11\%), 9 workers in the left ear (10.11\%) and 12 workers in both ears (13.48\%). There is no difference in the distribution of hearing loss based on DPOAE and pure tone audiometry (PTA) results with significance level $(p=0.051)$. SNHL determined from DPOAE refer result and PTA result where air conduction and bone conduction are more than $25 \mathrm{~dB}$ and no air bone gap. While NIHL determined from PTA result where there is notch at high frequency $4000 \mathrm{~Hz}$ and $6000 \mathrm{~Hz}$ (Table 7). In this study we didn't measured the average hearing thresholds in subjects.

\section{Discussion}

In this study, the age of the research subjects who experienced the most hearing loss was in the age range of 50-59 years, then followed by the age range of $40-49$ years. Statistical analysis shows significant differences in the distribution of hearing loss based on age. This is in line with research conducted by Rahayu and Pawenang ${ }^{5)}$ which shows that the age of $\geq 40$ years is the age at risk of hearing loss and variables that have a significant relationship with the incidence of hearing loss are age variables. Smedje, et al., ${ }^{6}$ in his study concluded that hearing ability decreases with increasing age.

In this study it was found that out of a total of 89 research subjects, the number of subjects with male sex was more than women. However, there is no difference in the distribution of hearing loss based on gender. WHO data in 2011 showed that the male population experienced more hearing loss than women with a ratio of $56 \%: 44 \%$. ${ }^{1}$

In this study workers who experience the most hearing loss

Table 6. Distribution of hearing loss based on DPOAE

\begin{tabular}{lcccc}
\hline \multirow{2}{*}{ DPOAE } & \multirow{2}{*}{ Pass } & \multicolumn{2}{c}{ Refer } & \multirow{2}{*}{ Total } \\
\cline { 3 - 4 } & & Unilateral & Bilateral & \\
\hline Total & $42(47.19)$ & $18(20.23)$ & $29(32.58)$ & $89(100)$ \\
\hline
\end{tabular}

Variables are presented as number (percentage). DPOAE: distortion product otoacoustic emission

Table 7. Distribution of hearing loss based on pure tone audiometry

\begin{tabular}{|c|c|c|c|c|c|c|}
\hline \multirow{2}{*}{ Audiogram } & \multirow{2}{*}{ Normal } & \multirow{2}{*}{ SNHL } & \multicolumn{3}{|c|}{$\mathrm{NIHL}$} & \multirow{2}{*}{ - Total } \\
\hline & & & Right ear & Left ear & Bilateral & \\
\hline Total & $\begin{array}{c}42 \\
(47.19)\end{array}$ & $\begin{array}{c}17 \\
(19.11)\end{array}$ & $\begin{array}{c}9 \\
(10.11)\end{array}$ & $\begin{array}{c}9 \\
(10.11)\end{array}$ & $\begin{array}{c}12 \\
(13.48)\end{array}$ & $\begin{array}{l}89 \\
(100)\end{array}$ \\
\hline
\end{tabular}

Variables are presented as number (percentage). $p=0.051$. SNHL: sensory-neural hearing loss, $\mathrm{NIHL}$ : noise induced hearing loss in workers with a working period of 17-21 years. Statistical analysis shows there are differences in the distribution of hearing loss based on working periode. This is also in line with the theory delivered by Bashiruddin,") namely that the longer a person is exposed to noise, the person is more susceptible to hearing loss. Workers who have or are working in a noisy environment for a long period of time, namely 5 years or more. These results are also in accordance with the research conducted by Tantana ${ }^{8)}$ shows that the factors significantly influenced is the exposure period. There is correlation between working periode and hearing loss due to ears exposed to noise. An increase in hearing threshold at first occurs temporarily (temporary threshold shift), but over time the ears no longer feel disturbed because there has been an increase in the hearing threshold, which is the accumulation of residual deafness from the temporary threshold shift then changes to become permanent.

Ear protectors (EP) provided by the company are uncorded with reduction power of $33 \mathrm{~dB}$. The highest noise intensity at the airport is $93.4 \mathrm{~dB}$ at a distance of about 5 meters from the aircraft, so the EP provided is effective in reducing noise to below $85 \mathrm{~dB}$ for 8 hours of work hours per day. But in reality on the ground there are still many workers who have not used EP while working because they feel uncomfortable. In this study, workers who rarely or did not use EP had more hearing loss than those who used EP. However, from statistical analysis, there is no difference in the distribution of hearing loss based on the use of EP. Previous research by Hong, et al.,") shows that workers using EP continuously experience fewer hearing problems than workers who rarely or do not use EP.

In this study, most research subjects worked in the silver ramp and apron services section. The workers who experience the most hearing loss are in the export-import cargo area, and the least experienced hearing loss is in the administration area. However, statistical analysis shows no differences in the distribution of hearing loss based on working area in the airport apron. Previous research by Kawatu, et al., ${ }^{10)}$ namely mild hearing loss in groung handling workers of $53.30 \%$ in the right ear, $30 \%$ in the left ear, while in the administration only $10 \%$ in both ears.

The results of the study obtained 47 workers (52.81\%) with the results of the DPOAE refer. Of these, 17 workers (19.11\%) and those who experienced NIHL were 30 workers (33.7\%). Workers who experienced NIHL were 9 workers in the right ear (10.11\%), 9 workers in the left ear (10.11\%) and 12 workers in both ears $(13.48 \%)$. In this study there is no difference in the distribution of hearing loss based on DPOAE and PTA re- 
sults. This result in accordance with the study by Manyakori, et al., ${ }^{11)}$ concluded that DPOAE and audiometry examinations did not make a significant difference in detecting hearing loss due to noise (NIHL).

The results of research from 89 research subjects, as many as $47(52.81 \%)$ workers with DPOAE refer examination results. A total of 30 people (33.7\%) of whom suffered from NIHL 9 in the right ear $(10.11 \%), 9$ in the left ear $(10.11 \%)$ and 12 in the right-left ear (13.48\%). Further research with larger samples is needed to get more complete and good results. The hearing loss conservation program needs to be implemented immediately in the work environment of Juanda airport in Surabaya.

\section{ORCID}

Nyilo Purnami https://orcid.org/0000-0002-2090-0992

\section{Author Contribution}

Conceptualization: Citra Dwi Novastuti, Nyilo Purnami, Nugraenny Affianti. Data curation: Citra Dwi Novastuti. Formal analysis: Nyilo Purnami. Funding acquisition: Citra Dwi Novastuti. Investigation: Nyilo Purnami. Methodology: Citra Dwi Novastuti, Nugraenny Affianti. Project administration: Citra Dwi Novastuti, Nugraenny Affianti. Resources: Citra Dwi Novastuti, Nugraenny Affianti. Software: Nugraenny Affianti. Supervision: Nyilo Purnami. Validation: Citra Dwi Novastuti, Nyilo Purnami. Visualization: Citra Dwi Novastuti, Nyilo Purnami, Nugraenny Affianti. Writing-original draft: Citra Dwi Novastuti. Writing-review \& editing: Nyilo Purnami.

\section{REFERENCES}

1) who.int [homepage on the Internet]. Deafness and hearing loss.
Geneva: World Health Organization [cited 2018 Nov 10]. Available from: URL: http://www.who.int/mediacentre/ factsheets/fs300/en/.

2) Hong OS, Kerr MJ, Poling GL, Dhar S. Understanding and preventing noise-induced hearing loss. Dis Mon 2013;59(4):110-8.

3) Azizi MH. Occupational noise-induced hearing loss. Int J Occup Environ Med 2010;1(3):116-23.

4) Iskandar M. Peraturan menteri tenaga kerja dan transmigrasi Republik Indonesia Nomor 13/MEN/X/2011 tentang nilai ambang batas faktor fisika dan faktor kimia di tempat kerja. Jakarta: Ministry of Manpower and Transmigration of The Republic of Indonesia; 2011.

5) Rahayu P, Pawenang ET. Faktor yang berhubungan dengan gangguan pendengaran pada pekerja yang terpapar bising di unit spinning di PT. Sinar Pantja Djaja Semarang. Unnes Journal of Public Health 2016;5(2):140-8.

6) Smedje G, Lunden M, Gärtner L, Lundgren H, Lindgren T. Hearing status among aircraft maintenance personnel in a commercial airline company. Noise Health 2011;13(54):364-70.

7) Bashiruddin J. Program konservasi pendengaran pada pekerja yang terpajan bising industri. Maj Kedokt Indon 2009;59(1):14-9.

8) Tantana O. Hubungan Antara Jenis Kelamin, Intensitas Bising dan Masa Paparan dengan Risiko Terjadinya Gangguan Pendengaran Akibat Bising Gamelan Bali Pada Mahasiswa Fakultas Seni Pertunjukan. E-Jurnal Medika Udayana 2014;3(3).

9) Hong O, Kerr MJ, Poling GL, Dhar S. Understanding and preventing noise-induced hearing loss. Dis Mon 2013;59(4):110-8.

10) Kawatu PAT, Rattu JAM, Tampubolon YD. Perbedaan nilai ambang dengar antara tenaga kerja ground handling dengan pegawai administrasi di bandar udara Sam Ratulangi Manado [dissertation]. Manado: Universitas Sam Ratulang;2012.

11) Nyilo P, Serafika Permoni Putri M. The association of reactive oxygen species levels on noise induced hearing loss of high risk workers in Dr. Soetomo General Hospital Surabaya, Indonesia. Indian J Otolaryngol Head Neck Surg 2018;71(1):1-4. 